\title{
RUBRYCELE DIECEZJI KRAKOWSKIEJ Z LAT 1735-1811 PRZECHOWYWANE W KSIECGOZBIORZE PODRECCZNYM ARCHIWUM KURII METROPOLITALNEJ W KRAKOWIE
}

\section{Streszczenie}

W księgozbiorze podręcznym Archiwum Kurii Metropolitalnej w Krakowie przechowywany największy znany zbiór kalendarzy liturgicznych drukowanych dla potrzeb duchowieństwa diecezji krakowskiej. Od połowy XVIII w. zbiór jest prawie kompletny.

Zgodnie ze zmodyfikowaną klasyfikacją przyjętą przez ks. Stanisława Librowskiego, krakowskie kalendarze liturgiczne można podzielić na cztery rodzaje, ściśle wiązane z fazami ich rozwoju. Do pierwszego typu należą kalendarze liturgiczne wydawane bez żadnych dodatków (XVI w. do 1750), do drugiego - kalendarze z spisem zmarłych duchownych (od 1751) oraz katalogiem prałatów i kanoników katedralnych (od 1753). Do trzeciego rodzaju rubrycel należą druki połączone z pełnym katalogiem parafii i duchowieństwa (od 1811), do czwartego - samoistne druki zawierające oddzielnie kalendarz liturgiczny i schematyzm diecezji pojawiły się dopiero od $1871 \mathrm{r}$.

Do końca XVIII w. zazwyczaj za wydanie rubrycel odpowiadały kapituły katedralne. W imieniu ordynariusza bądź wikariusza kapitulnego jeden z kanoników lub wikariuszy katedralnych, którego imię i nazwisko z reguły podawano na stronie tytułowej, opracowywał tekst. Do kapituły należały organizacja druku oraz dystrybucja kalendarza. W Krakowie kalendarz redagowali kolejni wicedziekani katedry wawelskiej, którzy równocześnie byli kanonikami kolegiaty św. Jerzego na Wawelu.

Trzeba również wspomnieć, że w zachowanych egzemplarzach rubrycel znajdują podpisy właścicieli rubrycel, które pozwalają poznać historię powstania kolekcji. Często również w zachowanych egzemplarzach kalendarzy znajdują się uwagi poczynione przez właścicieli. Dotyczą one kwestii ducho-

* Ks. Jan Szczepaniak - prof. historii, Instytut Historii, Uniwersytet Papieski Jana Pawła II w Krakowie, e-mail: jan.szczepaniak@upjp2.edu.p1

https://orcid.org/0000-0001-5365-8146 
wych i gospodarczych, dostarczając informacje o ważnych dla duchownych sprawach.

Słowa kluczowe: kalendarze liturgiczne (rubrycele); diecezja krakowska; schematyzmy (katalogi) duchowieństwa; wikariusze katedry wawelskiej; kolegiata św. Jerzego na Wawelu; drukarnie w Krakowie (XVIII w.).

Kalendarz liturgiczny, w którym umieszczano praktyczne wskazania dotyczące przebiegu poszczególnych okresów roku liturgicznego, ze szczególnym uwzględnieniem przepisów sprawowania liturgii godzin (brewiarza), celebrowania mszy św. i nabożeństw oraz przepisów postnych, należy do oficjalnych druków kościelnych, wydawanych z polecenia ordynariusza diecezji lub przełożonego zakonu ${ }^{1}$. Drukowane rubrycele pojawiły się w polskich diecezjach na początki XVI w. Pierwszy znany kalendarz dla diecezji krakowskiej pochodzi z 1507 r. ${ }^{2}$ W bibliografii Estreichera odnotowano fakt zachowania w polskich zbiorach bibliotecznych licznych rubryceli dla diecezji krakowskiej od 1526 r. do końca XVIII stulecia.

W księgozbiorze podręcznym Archiwum Kurii Metropolitalnej przechowywany jest znaczny zbiór kalendarzy liturgicznych drukowanych dla duchowieństwa diecezji krakowskiej. Z pierwszej połowy XVIII w. zachowało się tylko trzy egzemplarze z lat 1735, 1738 i 1745 . Od 1750 r. zbiór jest prawie kompletny. Brakuje tylko 9 roczników z 2. połowy XVIII w. (1753, 1754, 1755, 1756, 1775 , $1779,1781,1784,1789)$ oraz 8 roczników z XIX w. (1802-1804, 1806, 1808$1810,1839)$.

Zgodnie ze zmodyfikowaną klasyfikacją przyjętą przez ks. Stanisława Librowskiego druki te można podzielić na cztery rodzaje, ściśle wiązane $z$ fazami ich rozwoju. Do pierwszego typu należą pierwotne kalendarze liturgiczne, do drugiego - kalendarze liturgiczne z elementami schematyzmów diecezjalnych (zwykle z katalogami prałatów i kanoników katedralnych oraz spisem zmarłych duszpasterzy), do trzeciego - rubrycele połączone z pełnym katalogiem parafii

${ }^{1}$ E. Chomentowska, Schematyzmy zakonów męskich z ziem dawnej Rzeczpospolitej z lat 17181918. Studium źródłoznawcze, Lublin 2016, s. 39-40; Kalendarz, w: Encyklopedia wiedzy o książce, red. A. Birkenmajer i J. Trzynadlowski, Wrocław-Warszawa-Kraków 1971, kol. 1087-1092; X.S. Ch. [S. Chodyński], Dyrektorium, directorium, w: Encyklopedja Kościelna podtug teologicznej encyklopedji Wetzera $i$ Weltego z licznemi jej dopetnieniami, wyd. Nowodworski, t. 4, Warszawa 1874, s. 416-420; X. M. S. [M. Stefanowski], Rubrycela, w: Podręczna encyklopedya kościelna, red. S. Gall, J. Gautier, R. Jałbrzykowski i.in., t. 23-24, Warszawa-Lublin-Łódź 1914, s. 853.

2 Datę wydania najstarszego zachowanego kalendarza liturgicznego ustaliła i podała do publicznej wiadomości na konferencji w Kielcach dotyczącej rubrycel i schematyzmów diecezjalnych Alina Baran (tytuł referatu: Szesnastowieczne rubrycele diecezji krakowskiej w zbiorach Biblioteki Jagiellońskiej). Większość z zachowanych szesnastowiecznych rubrycel wydobył Kazimierz Piekarski z opraw rękopisów i książek, ponieważ były wykorzystywane przez introligatorów jako makulatura. Wcześniejsi badacze podawali, że pierwszy znany kalendarz dla diecezji krakowskiej pochodził z 1509 r. S. Konarska-Zimnicka, Konferencja naukowa „Rubrycele i schematyzmy Kościoła w Polsce, Kielce 23-25 maja 2014, „Archiwa Biblioteki i Muzea Kościelne” (dalej: ABMK), 102 (2014) s. 439; X. S. Ch. [S. Chodyński], Dyrektorium, directorium, s. 418-419; A. Konieczny, Rubrycela, w: Encyklopedia katolicka, t. 17, red. E. Giglewicz, Lublin 2012, kol. 513-514. 
i duchowieństwa, do czwartego - samoistne druki zawierające oddzielnie kalendarz liturgiczny i schematyzm diecezji ${ }^{3}$.

Spośród kalendarzy zestawionych dla diecezji krakowskiej, jak już wspomniano, do pierwszego typu należą druki wydawane od początku XVI w. do $1751 \mathrm{r}$. Rubrycela na rok 1751 r. otwiera nowy typ . Od tego roku zaczęto bowiem dodawać do kalendarza i przepisów liturgicznych spis zmarłych księży. Dwa lata późnej wprowadzono informacje o obsadzie personalnej beneficjów w krakowskiej kapitule katedralnej. Trzeci typ rubryceli pojawił się w diecezji krakowskiej w 1811 r. Wówczas do kalendarza na rok następny dołączono pełny spis parafii i duchowieństwa. Całkowite oddzielenie rubrycel i schematy zmów nastąpiło dopiero w 1871 r., otwierając trwającą do dziś praktykę oddzielnego wydawania rubrycel i schematyzmów.

\section{Proweniencja rubrycel}

Dotychczas nikt nie badał proweniencję krakowskiego zbioru rubrycel i schematyzmów diecezjalnych. Szczególnie dotyczy to druków z XVIII i początku XIX wieku. W późniejszych latach we wszystkich polskich konsystorzach i kuriach, a następnie $\mathrm{w}$ archiwach diecezjalnych gromadzono rubrycele i schematyzmy wysyłane przez wydawców. Pochodzenie starszych druków może ustalić przy pomocy tzw. znaków proweniencyjnych. Historycy dziejów książek i bibliotek dzielą je na: zapisy własnościowe, zapisy dedykacyjne, ekslibrisy i superekslibrisy, znaki biblioteczne i sposób oprawiania książek ${ }^{4}$.

Ze wszystkich tych znaków w opisywanych tutaj rubrycelach odnaleziono tylko zapisy własnościowe i w trzech przypadkach odręczne notatki, które pozwalają poznać właściciela kalendarza, a w ślad za tym rozpoznać drogę jaką rubrycele trafiły do archiwum kurialnego. Pierwsza część znaków własnościowych związana jest z osobami redagującymi rubrycele, o których będzie jeszcze mowa. Na okładce rubryceli wydanej na rok 1761 podpisał się ks. Jan Kanty Jurdziński, redagujący kalendarz w latach $1757-1783^{5}$. Na marginesie kalendarzy na lata 1795 i 1796 widnieją zaś uwagi korektorskie, zaaprobowane na ostatniej stronie kalendarzy (,probatio calami”). W katalogu na 1793 r. są również nieliczne poprawki i uzupełnienia, które należy uznać, jak w poprzednich przypadkach, za napisane ręką redaktora. W 1793 r. był nim Tomasz Mączyński, a w 1795 r. i następnym Tomasz Komperdowicz. Egzemplarze redakcyjne rubryceli musiały być własnością konsystorza krakowskiego, w jakieś mierze nadzorującego proces ich przygotowania.

${ }^{3}$ S. Librowski, Katalog rubrycel i schematyzmów diecezji i zakonów historycznej Polski znajdujacych się w księgozbiorze podręcznym Archiwum Diecezjalnego we Włocławku, cz. 1, ABMK, 23 (1971), s. 214.

${ }^{4}$ M. Pidłypczak-Majerowicz, Badania proweniencyjne $w$ bibliotekach kościelnych, „Fides. Biuletyn Bibliotek Kościelnych”, 2014 nr 1 (38) s. 4, 7, 10-11.

${ }^{5}$ Ponieważ częścią artykułu jest katalog rubryceli z lata 1735-1811, autor omawiając zbiór zachowanych kalendarzy liturgicznych nie odwołuje się w przypisach do tomików opisanych w katalogu,. Dodatkowym argumentem taką decyzją jest to, że rubrycele z tych lat nie mają paginacji i odwołanie byłoby powieleniem informacji zawartych w katalogu. 
W rubrycelach wydanych na lata $1759,1765,1773$ oraz 1800, 1801, 1805, 1807 i 1810 znalazły się podpisy duchownych związanych z kościołem św. Marka w Krakowie. W trzech pierwszych przypadkach są to markowie, Cyryl Kossa i Adrian Bronkalski, zakonnicy z klasztoru przy kościele św. Marka, w pozostałych rektor domu księży emerytów ks. Walenty Janikowski.

Cyryl Koss, s. Jacka; wstąpił do zakonu ok. 1750 r. Przyjął w Krakowie święcenia subdiakonatu 22 grudnia 1753 r., diakonatu 18 grudnia 1756 r. i prezbiteratu 18 stycznia $1757 \mathrm{r}$. W latach 1755-1758 pełnił obowiązki prokuratora w Trzcianie. Następnie był podprzeorem w Krakowie i prokuratorem prowincji polskiej $(1763,1765,1769)$. Prokurator (1771-1772 i 1775), podprzeor (17721773) i kaznodzieja (1773) w klasztorze św. Marka w Krakowie 6 .

Drugim z marków podpisanym na rubryceli był Adrian Bronkalski. Urodził się w 1731 r. Święcenia prezbiteratu przyjął 31 maja 1760 r. w Krakowie. Był profesor filozofii (1767) i teologii (1769) w studium zakonnym. Przez trzy kadencje pełnił obowiązki przeora klasztoru św. Marka w Krakowie (1768-1769, 1781-1783, 1784-1792). Tyleż razy był także przeorem klasztoru Trójcy Świętej i plebanem w Bogorii (30 XII 1785 - po 1787, 1792, ? -6 V 1806). W 1789 r. wybrano go na prowincjała prowincji polskiej. W latach 1791-1792 pełnił obowiązki wizytatora tej prowincji, a w latach 1792-1793 pierwszego asystenta generała zakonu. Był także podprzeorem (1 VII 1807-1808) i przeorem (19 I 1808-15 IV 1816) klasztoru św. Małgorzaty w Trzcianie. Po kasacie klasztoru został administratorem w Tarnawie k. Bochni (1813 - 15 IV 1816). Jako emeryt rezydował Królówce, gdzie zmarł 15 października 1817 r. ${ }^{7}$

Właścicielem kalendarzy wydanych na początku XIX w. był ks. Walenty Janikowski, rektor kościoła św. Marka i znajdującego się przy nim domu księży emerytów. Niewiele wiemy o jego młodości. Karierę duchowną rozpoczynał u cystersów. W 1784 r, mając już święcenia prezbiteratu, przebywał w konwencie szczyrzyckim. Sekularyzował się i został w 1787 r. wikariuszem w Bobowej. W latach 1789-1796 był plebanem w Krużlowej. Następnie zrezygnował z beneficjum plebańskiego i przyjął posadę wikariusza w Nowym Sączu (w tym czasie odbył rekolekcje w klasztorze Franciszkanów-Reformatów w Wieliczce). Przed 1800 r. był wikariuszem w Ciężkowicach. W latach 1800-1824 pełnił obowiązki rektora domu księży emerytów w Krakowie. Od 1812 r. aż do śmierci był posesorem prepozyturalnego beneficjum parafii św. Mikołaja w Krakowie. W latach 1817-1856 wspomniane wyżej funkcję łączył z obowiązkami obrońcy węzła małżeńskiego w sądzie biskupim w Krakowie. Posiadał godność kanonika honorowego kapituły kieleckiej. Zmarł 4 października $1858 \mathrm{r}^{8}$

${ }^{6}$ A. Bruździński, Kanonicy regularni od pokuty na ziemiach polskich, Kraków 2003, s. 176, 198,368 .

${ }^{7}$ Archiwum Kapituły Krakowskiej w Krakowie (dalej: AKKK) Reg. C. 26 s. 10, 56; Archiwum Kurii Metropolitalnej w Krakowie (dalej: AKMKr) AEp. 114 k. 514v; Bruździński, Kanonicy regularni, s. 369; A. Nowak, Stownik biograficzny kapłanów diecezji tarnowskiej 1786-1985, t. 2, Tarnów 2000, s. 88.

${ }^{8}$ AKKK Reg. C. 25 s. 51; Elenchus ...1812-1859; R. Majkowska, Archiwum kościoła św. Marka w Krakowie, „Nasza Przeszłość”, 71 (1989) s. 137-145; A. Nowak, Stownik biograficzny, t. 2, s. 291. 
Rubrycele marków i ks. W. Janikowskiego zapewne trafiły do księgozbioru konsystorskiego w trakcie licznych przenosin dokumentów i książek znajdujących się w klasztorze i kościele św. Marka, pierwotnie będących własnością krakowskich marków i duchaków oraz stanowiących spuścizną po domu księży emerytów9 .

W pozostałych trzech przypadkach można poznać nazwiska właścicieli rubryceli, duszpasterzy z zawiślańskiej części diecezji krakowskiej. Z zapisów metrykalnych zrobionych w kalendarzu na rok 1774 wynika, że jego właścicielem był ks. Sebastian Górowicz, pleban z Przytkowic. Notatki poczynione na rubryceli na rok 1777 r. świadczą, że korzystał z niej Szymon Banaczkowski, proboszcz w Mikluszowic. W katalogu na rok 1783 r. na wewnetrznej stronie okładki podpisał się ks. Marcin Skoblowski, mansjonarz w Stopnicy.

Pierwszy z nich - ks. S. Górowicz (Gurowicz, Gorowicz), s. Tomasza, urodził się w 1736 w Hecznarowicach. Do kapłaństwa przygotowywał się w Seminarium Akademickim (był w nim przynajmniej w latach 1762-1763). Wszystkie święcenia kapłańskie przyjął w Krakowie (t.m. ${ }^{10} 9$ VI 1759, s. ${ }^{11} 26$ II 1763, d. ${ }^{12} 2$ IV 1763, p. ${ }^{13} 28$ V 1763). Po opuszczeniu seminarium był wikariuszem w Sieprawiu (posadę otrzymał 23 VII 1762 r., przed święceniami subdiakonatu). Następnie pełnił obowiązki wikariusza w Zebrzydowicach do 1770 r. Później przyjął beneficjum plebańskie w Przytkowicach (12 VI 1770 - 5 II 1778), które dopełnił altarią Wniebowzięcia NMP, śś. Wojciecha, Jerzego i Anny w Zatorze (25 II 1777 - 1816). W 1778 r. przeniósł się na beneficjum plebańskie do Zatora, gdzie zmarł 4 grudnia 1816 r. $^{14}$

Kolejny właściciel rubryceli, to ks. S. Banaczkowski, s. Wojciecha. Pochodził on z Krakowa i tutaj się kształcił. W 1750 r. wraz z bratem Janem immatrykulowali się na Akademii Krakowskiej. Bakalaureat uzyskał w 1752 r., a magistrium atrium $20 \mathrm{~V} 1757$ r. Rok później przyjął tonsurę i cztery niższe święcenia kapłańskie (23 IX 1758 r.). Doktorem filozofii został 20 września 1760 r. Dwa lata później (10 IV 1762 r.) przyjął święcenia subdiakonatu (tytuł kanoniczny: altarysta przy wielkim ołtarzu - 2 ministerium w kościele Mariackim w Krakowie, beneficjum otrzymał 27 marca 1762 r. i był jego posesorem do 1770 r.). Otrzymał instytucję na scholasterię wojnicką (3 X 1766 r.), którą dzierżył do śmierci. W 1768 r. został członkiem Kolegium Mniejszego, a później Kolegium Prawników w Akademii Krakowskiej. W tymże roku został oddelegowany do pracy w Akademii Lubrańskiego w Poznaniu. Równocześnie pełnił funkcję prefekta seminarium duchownego. Wrócił do Krakowa w 1773 r. Wówczas objął beneficjum plebańskie w Mikluszowicach, otrzymane już 22 lipca 1770 r. i został mianowany

${ }^{9}$ Skomplikowane dzieje archiwaliów i książek z kościoła i klasztoru św. Marka w Krakowie opisała Rita Majkowska. Zob. Archiwum kościoła św. Marka w Krakowie, s. 137-145.

${ }^{10}$ t.m.- pierwsza tonsura i cztery niższe święcenia kapłańskie.

${ }^{11}$ s. - subdiakonat.

${ }^{12}$ d. - diakonat.

${ }^{13} \mathrm{p}$. - prezbiterat.

${ }^{14}$ AKMKr AOff. 194 s. 314-315; AKMKr AOff. 200 s. 585; AKMKr LOrd. 10 k. 34, 56, 57v, 58v; AKMKr Of. 54p s. 128; AKMKr Of. 55p s. 96; A. Nowak, Stownik biograficzny, t. 2 s. 242. 
wojnickim dziekanem foralnym. Pełnił obowiązki egzaminatora prosynodalnego dla całej diecezji krakowskiej, a następnie dla jej zawiślańskiej części. Zmarł 24 września 1784 r. na gruźlicę ${ }^{15}$.

Ostatnim duchownym korzystającym z rubryceli znajdującej się w omawianym zbiorze był ks. M. Skoblowski (Skoblewski, Skublewski), s. Tomasza. Urodził się 9 listopada 1752 r. w Rogoźniku (diec. krakowska). Do kapłaństwa przygotowywał się w Seminarium Zamkowym w Krakowie (5 IX 1772 - 1775). Wszystkie święcenia kapłańskie przyjął w tym mieście (t.m. 19 XII 1772, s. 11 III 1775, d. 1 IV 1775, p. 23 XII 1775). Po ordynacji na prezbitera był wikariuszem w Kazimierzy Wielkiej (od 12 I 1776 r.). Pełnił obowiązki wikariusza w Szaflarach (do 1782 r.) oraz wikariusza i mansjonarza w Stopnicy (1782-1783). Później pracował jako wikariusz w Jordanowie. Ok. 1795 r. został proboszczem w Spytkowicach k. Rabki, gdzie zmarł 28 VIII 1810 r. ${ }^{16}$

Brak związku ks. S. Górowicza i ks. M. Skoblowskiego z domem księży emerytów oraz z konsystorzem w Krakowie przemawiają za hipotezą, że rubrycele do nich należące były w posiadaniu parafii, w których pracowali i po zmianie granic diecezji w 1880 r. ${ }^{17}$ zostały przekazane do archiwum konsystorskiego.

Natomiast drugi wspomniany duchowny - ks. Szymon Banaczkowski, związany był z kolegiatą i parafią, która po 1880 i 1886 r. pozostałą w diecezji tarnowskiej. Najprawdopodobniej kalendarz używany przez niego w 1774 r. trafił do konsystorza w czasie pełnienia przez niego funkcji egzaminatora prosynodalnego diecezji krakowskiej.

\section{Redaktorzy}

Do końca XVIII w. za redagowanie i wydanie rubrycel zazwyczaj odpowiadały kapituły katedralne. W imieniu ordynariusza bądź wikariusza kapitulnego jeden z kanoników lub wikariuszy katedralnych, którego imię i nazwisko z reguły podawano na stronie tytułowej, opracowywał tekst. Do kapituły należały organizacja druku oraz dystrybucja kalendarza.

Z informacji zamieszczanych na pierwszej stronie krakowskich kalendarzy liturgicznych wynika, że tekst do druku przygotowywali księża: Jan Gorecki (1735), Jakub Kapuściński (1738), Wojciech Małocki (1745-1753), Jan Kanty Józef Jurdziński (1757-1783), Tomasz Mączyński (1785-1794), Tomasz Komperdowicz (1795-1798) i Franciszek Ceypler (1799-1807).

${ }^{15}$ AKMKr AOff. 194 s. 192-193; AKMKr AOff. 200 s. 616; AKMKr Descriptio ecclesiarum... s. 34; AKMKr LOrd. 10 k. 30, 51v; AKMKr Of. 44p s. 134; AKMKr Of. 51p s. 631; J. Szymański, Kapituła kolegiacka w Wojniczu 1465-1786, Lublin 1962, s. 148-149; W. Murawiec, H. Wyczawski, Banaczkowski Szymon, w: Słownik polskich teologów katolickich, red. H. Wyczawski, t. 1, Warszawa 1981, s. 95-96.

${ }^{16}$ AKMKr E 49 s. 29; AKMKr LOrd. 10 k. 98v, 100, 105; AKMKr LOrd. 12 s. 65; AKMKr Of. 53p s. 42; Archiwum Misjonarzy w Krakowie na Stradomiu (AMS) Ordo seu series alumnorum, s. 207; A. Nowak, Stownik biograficzny, t. 3, s. 67.

${ }^{17}$ B. Kumor, Granice (archi)diecezji krakowskiej (1000-1939), „Prawo Kanoniczne. Kwartalnik prawno-historyczny", 6 (1963) nr 1-4, s. 554-555. 
Pierwszy z nich J. Gorecki, s. Franciszka, pochodził z diec. krakowskiej. Nie wiadomo, gdzie uzyskał wykształcenie średnie i gdzie przygotowywał się do święceń kapłańskich. Pierwszą tonsurę i wszystkie jednak święcenia otrzymał w Krakowie (t.m. 2 VI 1703, s. 20 IX 1704, d. 28 IX 1704, p. 9 XI 1704). Po święceniach objął posadę wikariusz katedry na Wawelu (1704-1735), dochodząc w 1729 r. do godności wicedziekana. Po objęciu tej funkcji został kanonikiem prebendy Wojciechowska w kolegiacie św. Jerzego na Wawelu (8 VI 1729 - 1735). Zmarł w 1735 r. ${ }^{18}$

Kolejnym redaktorem rubrycel został jego następca J. Kapuściński, s. Franciszka. Urodził się on w 1707 r. w Będzinie. Studiował na Akademii Krakowskiej, a do kapłaństwa przygotowywał się w Seminarium Zamkowym (31 VIII 1729 1731). W Krakowie wszedł do stanu kapłańskiego i przyjął Wszystkie święcenia (t.m. 3 IV 1729, s. 29 IX 1730, d. 23 XII 1730, p. 17 II 1731). Pierwszą posadą był wikariat w katedrze wawelskiej (1731-1743). W kapitule mniejszej doszedł w 1735 r. do stanowiska wicedziekana. Otworzyło mu to drogę do otrzymania kanonii fundi Wojciechowska w kolegiacie św. Jerzego na Wawelu (9 VII 1735 1743). Był także plebanem w Brzozowej (15 XII 1735 - 1743) i Gołonogu (25 X 1743 - 1749). Zmarł w 1749 r. ${ }^{19}$

Po jego śmierci pieczę nad wydawaniem rubrycel przejął W. Małocki, wicedziekan (1744-1755) i altarysta św. Marii Magdaleny (do 1755 r.) w katedrze wawelskiej. Równocześnie otrzymał kanonię fundi Wojciechowska w kolegiacie św. Jerzego na Wawelu (31 I 1744 - 1755). Zmarł 9 grudnia $1755^{20}$.

Najdłużej przygotowywał do druku kalendarz liturgiczny dla diecezji krakowskiej J. K. J. Jurdziński, s. Stanisława. Pochodził on z diecezji krakowskiej. Nie wiemy gdzie uzyskał wykształcenie średnie i gdzie przygotowywał się do święceń kapłańskich. Pierwszą tonsurę i wszystkie święcenia przyjął w Krakowie (t.m. 16 III 1737, s. 15 VI 1737, p. 21 VII 1737). Pierwszą posadą jaką otrzymał po święceniach prezbiteratu był wikariat w Rzezawie (trzymał ją przynajmniej do 1748 r.). Od 1755 r. do śmierci był wicedziekanem katedry wawelskiej. Posiadał również inne beneficja w katedrze (angelista od 17 VI 1759 r. i altarysta św. Innocentego - 1 ministerium do 1769). Równocześnie z wicedziekaństwem otrzymał beneficjum kanonickie fundi Wojciechowska w kolegiacie św. Jerzego na Zamku Wawelskim (19 IX 1755). Zmarł 8 marca 1783 r. ${ }^{21}$

Po jego śmierci obowiązki redaktora kalendarza liturgicznego przejął T. Mączyński, s. Mateusza, urodzony ur. 11 XII $1741 \mathrm{w}$ dekanacie lipnickim, diecezji krakowskiej. Do kapłaństwa przygotowywał się w Seminarium Zamkowym (10 V 1763 - 21 IX 1765). Pierwszą tonsurę i wszystkie święcenia przyjął w Krakowie

${ }^{18}$ AKMKr LOrd. 6 s. 206, 248, 251, 253.

${ }^{19}$ AKMKr AOff. 172 s. 873; AKMKr AV 30 s. 249; AKMKr LOrd. 9 s. 60, 114, 120, 128; AKMKr Tabele Załuskiego 8, 4; AMS Ordo seu series alumnorum, s. 143; Rubricella 1751.

${ }^{20}$ AKMKr AEp. 93 s. 208; AKMKr AOff. 179 s. 69; AKMKr AOff. 184 k. 214; AKMKr Of. 40p s. 306; Rubricella 1757.

${ }^{21}$ AKMKr AEp. 113 k. 18; AKMKr AOff. 184 k. 214; AKMKr E 59 s. 888-889; AKMKr LOrd. 9 s. 262, 268, 271; AKMKr Of. 40 s. 305-306; AKMKr Of. 42p s. 354; AKMKr Of. 50p s. 275; Ordo 1784. 
(t.m. 26 II 1763, s. 22 XII 1764, d. 23 III 1765, p. 2 VI 1765). Był wikariuszem w katedrze wawelskiej (od 21 IX 1765 r. do śmierci). W kolegium wikariuszy katedralnych doszedł do godności wicedziekana (od 1783 r.), równocześnie uzyskując prebendę fundi Wojciechowska w kolegiacie św. Jerzego na Zamku Krakowskim (12 III 1783). W ostatnich latach życia był plebanem w Sączowie (od 7 XII 1790 r.). Zmarł tam 25 października 1793 r. ${ }^{22}$

Kolejnym odpowiedzialnym za przygotowanie krakowskiej rubryceli został T. Komperdowicz, s. Marcina. Urodził się on w 1742 r. w diecezji krakowskiej. Do kapłaństwa przygotowywał się w seminarium stradomskiego (23 II 1766 1767). Pierwszą tonsurę i wszystkie święcenia przyjął w Krakowie (t.m. $25 \mathrm{~V}$ 1766, s. 20 XII 1766, d. 4 IV 1767, p. 13 VI 1767). Całe życie kapłańskie związany był z katedrą wawelską. Był wikariuszem katedralnym od święceń subdiakonatu do śmierci, gdzie w 1793 r. doszedł do stanowiska wicedziekana, otrzymując związane z tym beneficjum fundi Wojciechowska w kolegiacie św. Jerzego na Wawelu (18 XII 1793). W katedrze pełnił również funkcję penitencjarz fundacji Dabscianae. Zmarł 1 grudnia $1797 \mathrm{r}^{23}$

Ostatnie rubrycele wydawane w XVIII stuleciu przygotowywał F. Ceypler, s. Józefa. Pochodził on z diecezji krakowskiej. Nie wiadomo gdzie uzyskał wykształcenie średnie oraz przygotowywał się do święceń kapłańskich. Pierwszą tonsurę i wszystkie święcenia kapłańskie uzyskał w Krakowie (t.m. 19 XII 1767, s. 23 IX 1769, d. 23 XII 1769, p. 10 III 1770). Całą posługę duchowną pełnił w katedrze wawelskiej na stanowisku wikariusza (od 1797 r. jako wicedziekan w kolegium wikariuszy). Zmarł w $1807 \mathrm{r}^{24}$

Wszyscy wymienieni redaktorzy rubryceli byli wicedziekanami katedry wawelskiej i równocześnie, do chwili kasaty, kanonikami kolegiaty św. Jerzego na Wawelu. Wszystko więc wskazuje na to, że w diecezji krakowskiej, przynajmniej w XVIII w. odpowiedzialnym za wydawanie rubryceli był każdorazowy wicedziekan katedry wawelskiej, który od czasu erygowania w 1688 r. był posiadaczem kanonii fundi Wojciechowska w kolegiacie św. Jerzego. Prebendę tę ufundował wikariusz katedralny ks. Walenty Sowiński (testamentem przekazał na ten cel 2000 florenów). W 1679 i 1680 r. wykonawcy testamentu zabezpieczyli majątek fundacyjny na dobrach ziemskich. W akcie fundacji zapisano, że patronem nowej kanonii będzie wicedziekani katedralny. Fundację zatwierdził i erygował kanonię 13 sierpnia 1688 r. bp Mikołaj Oborski, wikariusz generalny diecezji krakowskiej. Uposażenie posesora prebendy wynosiło 100 florenów rocznie ${ }^{25}$. Mimo łączenia beneficjum wicedziekańskiego z kanonią kolegiaty św. Jerzego obowiązek redagowania rubrycel spoczywał na ich posesorze ze względu na pełnienie

${ }^{22}$ AKKK Reg. C. 25 s. 7, 23; AKKK Reg. C. 26 s. 4, 26-27; AKMKr AEp. 113 k. 81; AKMKr E 59 s. 889; AKMKr LOrd. 10 k. 55v, 66, 67v; AKMKr LOrd. 12 s. 4; AMS Ordo seu series alumnorum, s. 196; Directorium 1795.

${ }^{23}$ AKKK Reg. C. 25 s. 23; AKKK Reg. C. 26 s. 4; AKMKr LOrd. 10 k. 73v, 75v, 77v, 79; AMS Catalogus clericorum, k. 25, 25v; AMS Memoryał przyjęcia konwiktorów, k. 2v; Directorium 1799.

${ }^{24}$ AKKK Reg. C. 25; AKKK Reg. C. 26; AKMK LOrd. 10 k. 81; AKMK LOrd. 12 s. 23, 26, 29; AMS Catalogus clericorum, k. 27, 28, 29.

${ }^{25}$ B. S. Kumor, Dzieje diecezji krakowskiej do roku 1795, t. 2, Kraków 1999, s. 479. 
funkcji wicedziekana, a nie kanonika. Zasada ta, którą kierowano się w diecezji krakowskiej była przyjmowana przez przyjmowana w całej Polsce, o czym wspomina ks. S. Librowski ${ }^{26}$

\section{Wydawcy i drukarnie}

Zachowane egzemplarze rubrycele pokazują, że przynajmniej od $1696 \mathrm{rr}^{27}$ do 1725 r. $^{28}$ wychodziły spod prasy oficyny Franciszka Cezarego. W 1616 r. jego dziadek, również Franciszek, być może wywodzący się z włoskiej rodziny złotniczej osiadłej w Krakowie, założył drukarnię, która dała początek firmie rodzinnej, znakomicie prosperującej do 1731 r. Po jego śmierci w 1651 r. zakład przejęła jego żona Barbara z Malickich, której pomagał najstarszy syn Jan Paweł (†1663). Prowadziła ona przy ul św. Anny drukarnię do 1665 r., do swojej śmierci. Ponieważ jej wnuk Franciszek, syn Jana Pawła, był wówczas niepełnoletni, schedą po niej zarządzali prawni opiekunowie. Drukarnia działała wówczas pod nazwą „Dziedziców”. Franciszek przejął ją w 1674 r. i zarządzał nią do śmierci w 1724 r. Ponieważ zmarły pozostawił wielu spadkobierców, dla zaspokojenia ich roszczeń koniecznym była sprzedaż drukarni i spłata wszystkich uprawnionych do spadku. W 1731 r. oficynę oraz jej siedzibę nabył profesor Akademii Krakowskiej Marcin Waleszyński, który trzy lata później przekazał nabytek uniwersytetowi ${ }^{29}$.

Następną drukarnią, której zlecono drukowanie kalendarzy dla diecezji krakowskiej była dawna drukarnia Schedla. Kupił ją w 1708 r. (transakcja potwierdzona w 1712 r.), po śmierci Mikołaja Aleksandra Schedla, księgarz Ignacy Antoni Hebanowski. Po jego zgodnie prowadzenie zakładu przejęła wdowa po nim - Róża i jej kolejni mężowie: Jakub Matyaszkiewicz i Dominik Wojciech Siarkowski. Pierwszy z nich odpowiadał za tłoczenie rubryceli przynajmniej od 1729 $\mathrm{r}^{30}$ może nawet do $1737 \mathrm{r}$.; drugi - od $1738 \mathrm{r}^{31}$ do $1746 \mathrm{r}{ }^{32}$

${ }^{26}$ S. Librowski, Katalog rubrycel, s. 215.

${ }^{27}$ Rubricella dioecesis Cracoviensis, juxta rubricas generales breviarij, \& missalis romani, ac decreta S. Rit. Congregat. ad annum Domini MDCLXLVII [...] consripta, [Cracoviae 1696]. Egzemplarz znajduje się w Bibliotece Uniwersytetu Warszawskiego pod sygn. 019697 - Stare Druki.

${ }^{28}$ Rubricella dioecesis Cracoviensis, juxta rubricas generales breviarij, \& missalis romani, ac decreta S. Rit. Congregat. ad annum Domini MDCCXXVI [...] consripta, [Cracoviae 1725]. Egzemplarz znajduje się w Bibliotece Uniwersytetu Jagiellońskiego pod sygn. 6701 (1726), I - Mag. St. Druk.

${ }^{29}$ K. Korotajowa, Cezary, w: Drukarze dawnej Polski od XV do XVII wieku, t. 1, Małopolska, cz. 2, Wiek XVII-XVIII, vol. 1, A-K, red. J. Pirożyński, Kraków 2000, s. 78-82.

${ }^{30}$ Rubricella dioecesis Cracoviensis, juxta rubricas generales breviarij, \& missalis romani, ac decreta S. Rit. Congregat. ad annum Domini MDCCXXX [...] consripta, [Cracoviae 1729]. Egzemplarz znajduje się w Bibliotece Uniwersytetu Warszawskiego pod sygn. 019697 - Stare Druki.

${ }^{31}$ Rubricella dioecesis Cracoviensis, juxta rubricas generales breviarij, \& missalis romani, ac decreta S. Rit. Congregat. ad annum Domini MDCCXXXVIII [...] consripta, [Cracoviae 1737]. Egzemplarz znajduje się w Bibliotece Uniwersytetu Warszawskiego pod sygn. 019697 - Stare Druki.

${ }^{32}$ Rubricella dioecesis Cracoviensis, juxta rubricas generales breviarij, \& missalis romani, ac decreta S. Rit. Congregat. ad annum Domini MDCCCXLVI[...] consripta, [Cracoviae 1745]. Egzemplarz znajduje się w Bibliotece Uniwersytetu Warszawskiego pod sygn. 019697 - Stare Druki. 
Jakub Matyaszkiewicz, s. Łukasza i Katarzyny, ur. ok. 1719 r. na Kleparzu. Ok. 1694 r. został czeladnikiem intrologatorskim. Wyzwoliwszy się na kilka lat opuścił miast i przeniósł się do Lwowa, gdzie prowadził kram introligatorski. W tymże mieście od 1704 r. związał się z księgarnią Andrzeja Ignacego Habanowskiego, drukarza krakowskiego i warszawskiego, początkowo jako subiekt, a od 1709 do 1715 r., po wyjeździe syna właściciela Ignacego Antoniego do Krakowa, jako kierownik. Ze względu na źle prosperującą księgarnię, popadł w konflikt z I. A. Hebanowskim, który oskarżył go o kradzież książek (został przez sąd uniewinniony). Przez kolejne lata pracował jako bibliotekarz Jerzego Dzieduszyckiego, koniuszego koronnego i starosty żydaczowskiego. W 1718 r. wrócił do Krakowa i rok później ożenił się z wdową po swoim zmarł pryncypale Różą Hebanowską, przejmując zarząd nad jej majątkiem - drukarnią i księgarnią, znajdującą przy ul. Floriańskiej 1. Działalność drukarską prowadził do swojej śmierci ok. $1738 \mathrm{r}^{33}$

Wspomniany wyżej D.W. Siarkowski, urodził się ok. 1706 r. W Krakowie uczył się introligatorstwa (wyzwolił się 12 III 1724 r.). Po odbyciu praktyki i uzyskaniu tytułu mistrzowskiego osiadł w Warszawie, gdzie prowadził warsztat i kram introligatorski oraz księgarnię. W 1739 r. ożenił się z Różą, wdową po I. A. Hebanowskim i J. Mataszkiewiczem. Nie rezygnując z firmy warszawskiej przejął krakowską drukarnię, zakład introligatorski i księgarnię swojej żony. Chcąc rozwijać swojej warszawskie przedsiębiorstwo doprowadził do upadku krakowską drukarnię, w tajemnicy przed żoną wysyłając do stolicy pieniądze, książki i sprzęt drukarski. W 1747 r., po wykryciu kradzieży, opuścił żonę i wyjechał do Warszawy. Mimo jego nieobecności rodzina żony wydrukowała kilka książek, m.in. rubrycele dla diecezji krakowskiej na lata 1747-1749, sygnując druki jego nazwiskiem. Zmarł w Warszawie w 1749 r. ${ }^{34}$

Jego śmierć zbiegła się z otwarciem przez bp A. S. Załuskiego drukarni. To ona przyjęła na siebie trud wydawania rubryceli. W 1747 r. bp Andrzej Stanisław Załuski sprowadził do Krakowa z Frankfurtu n. Odrą gisera Samuela Filipa Glasera i jego syna Teodora z zamysłem otwarcia drukarni biskupiej. Jej organizatorem został kanonik Andrzej Młodziejowski (pełnił ten obowiązek do chwili swojego wyjazdu do Rzymu w marcu 1748 r.). W 1748 r., za zgodą władz Akademii Krakowskiej, Glaserowie rozpoczęli odlewanie czcionek łacińskich, polskich, greckich, niemieckich, a później hebrajskich. Po odlaniu niezbędnego zestawu czcionek ordynariusz krakowski otworzył 1749 r. w pałacu biskupim oficynę drukarską. W 1756 r. drukarnię przeniesiono do własnego lokalu przy ul. Wiślnej. Zarządcami drukarni byli: Adam Klein (1752), Dominik Rofenmüller (1753-1756), Józef Hajek (1756-1757), ks. Antoni Piotr Frola (1757), Fabian Hebanowski (1759). Tworząc Seminarium Akademickie 2 grudnia 1757 r. przekazał

${ }^{33} \mathrm{~J}$. S. Bandtke, Historya drukarń krakowskich od zaprowadzenia druków do tego Miasta aż do czasów naszych, wiadomościa o wynalezieniu sztuki drukarskiey poprzedzona, Kraków 1815, s. 479-482; M. Grzeszczuk, Matyaszkiewicz Jakub, w: Drukarze dawnej Polski, cz. 2, vol. 2, s. $426-434$.

${ }^{34}$ J. S. Bandtke, Historya drukarń krakowskich, s. 482-483; M. Jaglarz, Siarkowski Dominik Wojciech, w: Drukarze dawnej Polski, cz. 2, vol. 2, s. 561-562. 
drukarnie (zastrzegając sobie prawo dożywocia) zarządowi seminarium. W dowód wdzięczności zarząd zobowiązał się dostarczyć corocznie na koszt drukarni 3000 oprawnych egzemplarzy rubryceli, na użytek diecezji krakowskiej. Miały być one dostarczone proboszczom bezpłatnie. W zamian za co zobowiązywali się do odprawienia jednej mszy św. w roku za fundatora seminarium i drukarni. Zapis zatwierdzono 13 grudnia 1758 r., na trzy dni przed śmiercią biskupa ${ }^{35}$.

Przejęta przez Akademię oficyna przyjęła nazwę: Drukarnia Seminarium Biskupio-Akademickiego. Administrował nią profesor ks. Cyprian Miller (do 1760 r.), a później Antoni Jarzęcki (do 1767 r.), Jan Ambroziewicz (do 1771 r.), Franciszek Kazimierz Wątrobski (do 1772), Marcin Bednarski (do 1774 r.), Maciej Tylkowski (do 1783 r.) i Bernard Rzążewski (do 1789 r.) ${ }^{36}$. W tym zakładzie drukowano kalendarze liturgiczne dla diecezji krakowskiej w latach 1760-1765 oraz 1768-1772.

W okresie kryzysu drukarni biskupio-akademickiej dwa roczniki rubryceli, na lata 1767-1768 wydano w księgarni Stanisława Stachowicza. Urodził się on ok. 1719 r. W 1733 r. został przyjęty do cechu introligatorskiego, uzyskując dwa lata później tytuł mistrza cechowego. Był znany w mieście, dwukrotnie pełniąc funkcję „króla kurkowego”, a następnie podstarszego i starszego cechu introligatorskiego. Dorobiwszy się na handlu winem węgierskim zainwestował w działalność typograficzną (przywilej na prowadzenie drukarni uzyskał od króla Augusta III Sasa w 1754 r.). W tymże roku otworzył pierwszą drukarnię w oficynie kamienicy „Pod Konikiem” (obecnie Rynek Główny 39). W 1758 r. wynajął, a w 1766 r. nabył kolejną drukarnię Michała Józefa Antoniego Dyaszewskiego. Zmarł 9 grudnia 1791 r. w Krakowie ${ }^{37}$.

Od 1776 r. do 1790 r. za wydanie rubrycel, jako nakładca odpowiadał Ignacy Grebel. Urodził się ok. 1741 r. na Śląsku. Do Krakowa przybył w 1755 r. i zatrudnił się u kupca Józefa Feistmantla, u którego przez osiem lat uczył się zawodu. W rok po uzyskaniu praw miejskich został 27 sierpnia 1764 r. przyjęty do kongregacji kupieckiej. Handlował towarami sprowadzanymi z Anglii, Austrii, Francji, Niemiec i Włoch. Uzyskane zyski pozwoliły mu na wynajęcie w 1771 r. drugiego sklepu, w którym założył księgarnię. Powodzenie z jakim spotkała się ta decyzja spowodowało otwarcie filii księgarskiej w Podgórzu, Tarnowie i Lublinie. Od 1776 r, a nie jak dotąd sądzono od 1779 r. rozpoczął działalność nakładczą. W 1779 r. zwrócił się do króla z prośbą o zgodę na prowadzenie drukarni. Mimo poparcia udzielonego przez magistrat miasta oraz podkanclerza Jana Jędrzeja Borcha przywilej otrzymał dopiero 12 maja 1781 r. (nie czekając na przywilej, w 1780 r. zorganizował przy ul. Grodzkiej 14 własną drukarnię). Zmarł 9 marca w

35 J. S. Bandtke, Historya drukarń krakowskich, s. 490; M. Gołuszka, Jaśnieoświeconego księcia biskupa krakowskiego Andrzeja Stanisława Załuskiego drukarnia w Krakowie 1749-1758, w: Drukarze dawnej Polski, cz. 2, vol. 2, s. 262-268; B. S. Kumor, Dzieje diecezji krakowskiej, s. 41-43; W. Müller, W. Szczygielski, Młodziejowski (Młodziejewski) Andrzaj Mikołaj, w: Polski Sownik Biograficzny, t. 21, red. E. Rostworowski, Wrocław 1976 s. 428-429.

${ }^{36}$ A. Kicińska-Fujawa, Akademii Krakowskiej Drukarnie, w: Drukarze dawnej Polski, cz. 2, vol. 1 , s. 49-50.

${ }^{37}$ M. Grzeszczuk, Stachowicz Stanistaw, w: Drukarze dawnej Polski, cz. 2, vol. 2, s. 594-596. 
1790 w Krakowie ${ }^{38}$. Jako nakładca korzystał z usług najpierw drukarni Kolegium Większego (1776), a później drukarni seminarium biskupio-akademickiego (17771783) i drukarni Szkoły Głównej Koronnej (1784-1789), mimo, że od 1780 r. mógł tłoczyć rubrycele we własnej drukarni.

Drukarnię Kolegium Większego założył w 1574 r. Andrzej Piotrkowczykowski. Jego wnuk Andrzej młodszy, najprawdopodobniej bezdzietny, w 1674 r. ofiarował oficynę Akademii Krakowskiej. Ta przyjęła darowiznę, zaspakajając roszczenia finansowe sióstr ofiarodawcy. Administrację typografii powierzono profesorowi Kolegium Większego i zarządcy majątku uniwersyteckiego Łukaszowi Piotrowskiemu. Po jego śmierci pieczę nad drukarnią zwyczajowo sprawowali członkowie Kolegium Większego, choć zakład był własnością całej Akademii i służył całej społeczności akademickiej. Druki wychodzące spod prasy tej drukarni, znajdującej się przy ul. Floriańskiej w domu „Pod Wiewiórką”, do reformy kołłątajowskiej były opatrzone notatką „Typis Collegii Maioris”39.

Po reformie drukarni uniwersyteckich przeprowadzonej przez Hugona Kołłątaja zarządzający diecezją i wybrany przez nich nakładca I. Grebel nadal zlecali drukowanie rubryceli drukarni akademickiej. Po scaleniu wszystkich oficyn pod zarządem ks. Franciszka Rzążewskiego powstała drukarnia nosiła nazwę: Drukarnia Szkoły Głównej Koronnej ${ }^{40}$. W drukarni tej kalendarze liturgiczne dla diecezji krakowskiej tłoczono do końca XVIII w.

Kalendarz liturgiczny docierał do wszystkich księży diecezjalnych i zakonnych w diecezji krakowskiej, zgodnie z zamysłem rządzących diecezją. W tym celu postulowano, żeby każdorazowo drukować rubrycelę w nakładzie 3000 egzemplarzy, co na owe czasy było wielkim przedsięwzięciem ${ }^{41}$. Czy tak było nie wiemy. Jeśli jednak przyjąć, że starano się zapewnić każdemu księdzu dostęp do kalendarza, to potrzeba było ok. 2000 egzemplarzy, bo tylu było wówczas duchownych diecezjalnych trudniących się duszpasterstwem. Zapewne również jakaś ilość rubrycel trafiała do kościołów i domów zakonnych oraz duchowieństwa diecezjalnego nie zajmującego się działalnością duszpasterską oraz instytucji kościelnych i państwowych ${ }^{42}$.

Dla wydawców i administratorów drukarni, którym zlecono tłoczenie katalogów ogromną pomocą w sprzedaży książek znajdujących się na ich składach było dotarcie do potencjalnych nabywców z listą publikacji możliwych do zakupienia. Po raz pierwszy opublikowano spis książek wydanych przez drukarnię

38 J. S. Bandtke, Historya drukarń krakowskich., s. 494; M. Grzeszczuk, Grebel Ignacy, w: Drukarze dawnej Polski, cz. 2, vol. 1, s. 224-225.

${ }^{39}$ J.S. Bandtke, Historya drukarń krakowskich, s. 491-494; A. Kicińska-Fujawa, Akademii Krakowskiej Drukarnie, w: Drukarze dawnej Polski, cz. 2, vol. 1, s. 42-46.

${ }^{40}$ Tamże, s. 50-54.

${ }^{41}$ M. Gołuszka, Jaśnieoświeconego księcia biskupa krakowskiego, s. 264.

${ }^{42}$ Relacja o stanie diecezji Krakowskiej bp. Kajetana Sołtyka z 1765 r. podaje, że w diecezji było ok. 2000 duchownych posiadających beneficja. Taką ilość duchownych diecezjalnych potwierdzają współczesna badania. W. Müller, Relacje o stanie diecezji krakowskiej 1615-1765, Lublin 1978, s. 177; J. Szczepaniak, Duchowieństwo diecezji krakowskiej: studium prozopograficzne, Kraków 2010, s. 118-119. 
biskupio-akademicką w rubryceli na rok 1760. Oprócz tego katalogi wydawnictw tej oficyny zamieszczono jeszcze 7 razy, rubrycelach na lata 1761-1764, 1769 i 1771-1772. Po przejęciu druku rubryceli przez J. Grebela ukazało się w niej 11 katalogów druków znajdujących się w jego księgarni, a po 1781 r. również przez niego wytłoczonych. Spisy te znalazły się jako dodatki do kalendarzy wydanych na lata: 1772-1774, 1777-1778, 1780, 1782-1783, 1786-1787 i 1790. Poza tymi spisami książek, wytłoczonymi w drukarniach akademicko-biskupiej i I. Grebela opublikowano w rubryceli na rok 1771 katalog książek religijnych księgarni Fabiana Sebastiana Drelinkiewicza, na rok 1795 jednostronicowy katalog książek znajdujących się w księgarni Jana Maya (ul. Floriańska) oraz na rok 1800 niewielki spis książek liturgicznych wydanych przez Uniwersytet Krakowski.

Opisany zbiór osiemnastowiecznych rubrycel dla diecezji krakowskiej należy do większych tego typu kolekcji w Polsce. Pozwala on prześledzić, a trwało w Krakowie od połowy XVIII do połowy XIX w., ewolucję diecezjalnych kalendarzy liturgicznych i wyodrębnienie z nich schematyzmów i urzędowych czasopism diecezjalnych. Rubrycele te znalazły się w podręcznej bibliotece kurialnego archiwum przynajmniej na trzy sposoby: 1. - jako spuścizna po kancelarii wikariusza generalnego, 2. - po przeniesieniu z archiwum domu księży emerytów znajdującego się przy kościele św. Marka oraz 3. - drogą pozyskania z archiwum parafialnych. W Krakowie rubrycele, tak jak w przypadku wielu polskich diecezji, były redagowane przez wicedziekanów kościoła katedralnego. Zazwyczaj drukowano je w drukarniach kościelnych i uniwersyteckich, niekiedy w drukarniach prywatnych wydawcy, bądź znanych w Krakowie zakładach rodzinnych. Publikowane w rubrycelach dokumenty kościelne: dekrety, przepisy liturgiczne, listy pasterskie i komunikaty pokazują zagadnienia i kwestie, którymi żyły ówczesne władze kościelne i duchowieństwo.

\section{REFERENCES / BIBLIOGRAFIA}

\section{Źródla rękopiśmienne}

Archiwum Kapituły Katedralnej w Krakowie (AKKK)

sygn. Reg. C. 25Compendium beneficiorum jurispatronatus S. R. Maiestatis tam curatorum quam simplicium in cathedrali et collegiatis dioecesis Cracoviensis in Polonia sitae, secundum quod exemplaria Varsoviam transmissa.

sygn. Reg. C. 26Compendiosa descriptio omnium ecclesiarum: cathedralis, collegiatarum et parochialium tum beneficiatorum tam curatorum quam simplicium cum oppidis et villis ad parochias pertinentibus in quibus palatinatibus, disctrictibus et decanatibus consistant, dioecesis Cracoviensis in Polonia sitae, ex libris generalium visitationum excepta et annotata, anno Domini 1786.

Archiwum Kurii Metropolitalnej w Krakowie (AKMKr)

sygn. AEp. 93[Acta actorum Celsissimi Illustrissimi et Reverendissimi Domini Andreae Stanislai Kostka in Załuskie Załuski, Dei et Apostolicae Sedis gratia episcopi Cracoviensis, ducis Severiae, annorum 1755 et 1756.]

sygn. AEp. 113Prothocollum actorum curiae episcopalis Cracoviensis a die 20 II 1782 ad ultimos XII 1783, stante infirmitate Celssimi Principis Domini Cajetanii Ignatii 
Sołtyk, episcopi Cracoviensis, administratore cum plena iurisdictione dioecesis Cracoviensis Celsissimo Illustrissimo et Reverendissimo Domino Michaele Georgio Ciołek principe Poniatowski, episcopo Plocensi, duce Severiae, abbate commendatario Cervenensi, decano Varsaviensi, ordinum Aquilae Albae et Sancti Stanislai equite conscriptum.

sygn. AEp. 114Acta actorum curiae episcopalis Cracoviensis annorum 1784 - 1785 stante infirmitate Celssimi principis Domini Cajetanii Ignatii Sołtyk, episcopi Cracoviensis, administratore cum plena iurisdictione dioecesis Cracoviensis Celsissimo Illustrissimo et Reverendissimo Domino Michaele Georgio Ciołek principe Poniatowski, episcopo Plocensi, duce Pultoviensi, coadiutore Cracoviens, duce Severiae, abbate commendatario Cervensi, decano Varsaviensi, ordinum Aquilae Albae et Sancti Stanislai equite, a mense aprili 1785, archiepiscopo Gnesnensi, legato nato, primate Regini Poloniae, administratore cum plena jurisdictione Cracoviensi, abbate commendatario Cervenensi et Tynecensi, ordinum regini equite conscripta,

sygn. AOff. 172 [Acta actorum Perillustris et Reverendissimi Domini Michaelis de Granow Wodzicki, canonici, vicarii in spiritualibus et officialis generalis Cracoviensis, custodis Visliciensis ab anno 1734 ad annum 1735 conscripta.]

sygn. AOff. 179Acta actorum Perillustris et Reverendissimi Domini Michaelis de Granow Wodzicki, canonici, vicarii in spiritualibus et officialis generalis Cracoviensis, abbatis commendatarii Vąchocensis, 1744.

sygn. AOff. 184[Acta actorum consistorii generalis Cracoviensis sub officialatu Illustrissimi et Reverendissimi Domini Michaelis in Magna Kunice Kunicki, episcopi Arsionensis, suffraganei, canonici, vicarii et officialis generalis Cracoviensis, abbatis commendatarii Clarae Tumbae, 1751.]

sygn. AOff. 194Acta actorum officialatus Illustrissimi et Reverendissimi Domini Francisci de Potkana Potkanski, Dei et Apostolicae Sedis gratia episcopi Patarensis, suffraganei, canonici, vicarii in spiritualibus et officialis generalis Cracoviensis, anni 1762di.

sygn. AOff. 200Acta actorum consistorii generalis Cracoviensis sub officialatu Illustrissimi et Reverendissimi Domini Francisci de Potkana Potkanski, Dei et Apostolicae Sedis gratia episcopi Patarensis, suffraganei, canonici, vicarii in spiritualibus et officialis generalis Cracoviensis, anno Domini 1768vo conscripta.

sygn. AV 30Status ecclesiarum seu acta visitationis decanatuum Novi Montis et Bythomien[sis] in Polonia sub auspiciis et felicissimo regimine Celsissimi principis Illustrissimi et Reverendissimi Domini, Domini Andreae Stanislai Kostka comitis in Załuskie Załuski, episcopi Cracoviensis, ducis Severiae, equitis Aquilae Albae, anno quo intra [1747 et 1748] conscripta.

sygn. E 50Prothocollum actorum curiae Celsissimi Illustrissimi et Reverendissimi Domini Michaelis Poniatowski, Dei et Apostolicae Sedis gratia episcopi Plocensis, ducis Pultoviensis, coatjutoris cum plene iurisdictione Cracoviensis, ducis Severiae, abbatis commendatorii Cervenensis, decani Varsaviensis, ordinum Aquilae Albae et Sancti Stanislai equitis, anni 1785.

sygn. E 59Prothocollon curiae 1791.

sygn. LOrd. 6Liber ordinatorum, portatilium, calicium et campanarum per Ill[ust]r[issi] mum et R[evere]nd[issi]mum D[omin]um, D[omin]um Stanislaum à Słupow Szembek, Dei et Ap[osto]licae Sendis gratia episcopum Dionisiensem, suffraganeum, canonieum, vicarium in spiritualibus et officialem generalem Cracoviensem, Anno Domini 1695 inceptus.

sygn. LOrd. 9Liber ordinatorum consecrationis ecclesiarum, capellarum altarium, immobilium, portatilium, calicium et campanarum per Illustrissimum et Reverendissimum 
Dominum Michaelem Kunicki, Dei et Apostolicae Sedis gratiae episcopu Arsinoensem, suffraganeum et archidiaconum Cracoviensem, custodem Sandomiriensem, Anno $1727 \mathrm{mo}$.

sygn. LOrd. 10Acta Illustrissimi et Reverendissimi Domini Domini Francisci de Potkana Potkanski, episcopi Patarensis, suffraganei, canonici, vicarii in spititualibus et officialis generalis Cracoviensis ad Anno Domini 1753 tio a die 29 mensis septembris, qua dies fuit dies consecrationis Illius in episcopum patarensem.

sygn. Of. 40pProtocollum actorum officialatus Perillustris et R[evere]ndissimi Domini Dominici Josephi in Kiełczew Kiełczewski, canonici, vicarii in Spiritualibus et officialis generalis Cracoviensis, Łoviciensis et Kielcensis praepositi, anno Domini 1756 to.

sygn. Of. 42p Protocollum actorum illustrissimi et Reverendissimi Domini Francisci de Potkana Potkański, Dei et Ap[osto]licae Sedis gratia episcopi Pateren[sis], suffraganei, canonici et sede vacante episcopates Cracoviensis ac ducatus Severiensis generalis administratoris, anno Dominii 1759 conscriptum.

sygn. Of. 44p.Protocollum actorum con[sisto]rii g[e]n[er]al[is] Craco[oviensis], anni 1762.

sygn. Of. 50p.Prothocollum actorum consistorii generalis Cracovien[sis], 1769[-1770]. sygn. Of. 51p.Prothocollum actorum consistorii generalis Cracovien[sis], 1771[-1773].

sygn. Of. 53pProtocollum actorum consistorii generalis Cracovien[sis], annus Domini 1776.

sygn. Of. 54pProtocollum actorum consistorii generalis Cracoviensis in annum Domini 1777.

sygn. Of. 55pProtocollum actorum consistorii generalis Cracoviensis anni Domini 1778. b. sygn.[Tabellae ecclesiarum. Decanatus: Bythomienis, Novi Montis, Oswecimensis, Zatoriensis et Zywecensis] (Tabele Załuskiego 8).

b. sygn. Descriptio ecclesiarum parochialium et beneficiorum consistentium cum circumstantiis in Tabella Normali ab Excelso Gubernio sub die 2da septembris anni elapsi porrecta specificatis facta, Anno Domini 1776.

Archiwum Misjonarzy w Krakowie na Stradomiu (AMS)

b. sygn. Catalogus clericorum alumnorum in seminario domus Stradomiensis Congregatio

Missionis commoratium per annos infraspecificandos [1732-1797].

b. sygn. Ordo seu series alumnorum Seminarii Cracoviensis conscriptus anno Domini

1677 die 25 januarii [3 V 1800, 28 VIII 1800- 1801].

b. sygn. Memoryał przyjęcia konwiktorów, 1763-1779.

\section{Źródła drukowane}

Müller W., Relacje o stanie diecezji krakowskiej 1615-1765, Lublin 1978.

Rubricella dioecesis Cracoviensis [...] ad annum Domini MDCLXLVII [...] consripta [...], [Cracoviae 1696].

Rubricella dioecesis Cracoviensis [...] ad annum Domini MDCCXXVI [...] consripta [...], [Cracoviae 1725].

Rubricella dioecesis Cracoviensis [...] ad annum Domini MDCCXXX [...] consripta [...], [Cracoviae 1729].

Rubricella dioecesis Cracoviensis [...] ad annum Domini MDCCXXXV [...] conscripta [...], [Cracoviae 1734].

Rubricella dioecesis Cracoviensis [...] ad annum Domini MDCCXXXVIII [...] consripta [...], [Cracoviae 1737]. 
Rubricella dioecesis Cracoviensis [...] ad annum Domini MDCCXLV-MDCCXLVI [...] consripta [...], [Cracoviae 1744-1745].

Rubricella dioecesis Cracoviensis [...] ad annum Domini MDCCL-MDCCLI [...] conscripta [...].[Cracoviae 1749-1750].

Rubricella dioecesis Cracoviensis [...] ad annum Domini MDCCLIII [...] conscripta [...].[Cracoviae 1752].

Rubricella dioecesis Cracoviensis [...] ad annum Domini MDCCLVII-MDCCLXXIV [...] conscripta [...]. [Cracoviae 1756-1773].

Rubricella dioecesis Cracoviensis [...] ad annum Domini MDCCLXXVI-MDCCLXXVIII [...] conscripta [...] .[Cracoviae 1775-1777].

Rubricella diaecesis Cracoviensis [...] ad annum Domini MDCCLXXX [...] conscripta [...]. [Cracoviae 1779].

Ordo officii Divini pro diaecesi Cracoviensi [...] ad annum Domini MDCCLXXXII -MDCCLXXXIII [...] conscriptus [...]. [Cracoviae 1781-1782]

Ordo officii Divini pro diaecesi Cracoviensi [...] ad annum Domini MDCCLXXXV -MDCCLXXXVII [...] conscriptus [...].Cracoviae [1784-1786].

Directorium officii Divini pro diaecesi Cracoviensi [...] ad annum Domini MDCCLXXXVIII [...] conscriptum [...]. Cracoviae [1787].

Directorium officii Divini pro diaecesi Cracoviensi [...] ad annum Domini MDCCXCMDCCXCII [...] conscriptum [...]. Cracoviae [1789-1791].

Ordo officii Divini pro diaecesi Cracoviensi [...] ad annum Domini MDCCXCIII [...] conscriptus [...] .[Cracoviae 1792].

Directorium officii Divini pro diaecesi Cracoviensi [...] ad annum Domini MDCCXCIVMDCCCI [...] conscriptum [...]. [Cracoviae 1793-1800].

Directorium officii Divini pro dioecesi Cracoviensi [...] ad annum Domini MDCCCV [...] conscriptum [...]. Cracoviae [1804].

Directorium officii Divini [...] pro anno Domini MDCCCVII [...] pro dioecesi Cracoviensi [...] conscriptum [...]. [Cracoviae 1806].

Directorium officii Divini [...] pro anno Domini MDCCCX-MCCCXI [...] pro dioecesi Cracoviensi [...] conscriptum [...]. [Cracoviae 1809-1810].

„Verordnungen des Lemberger lat[einischen] Metropolitan Konsistorium Militär-Jahr”, 1 (1844). Od 1854 r. zmiana nazwy: „Currendae Consistorii Metropolit[ani] r[itus] 1[atini] Leopol[iensis] in negotii ecclesiasticis ex anno[...]”.

\section{Opracowania}

Bruździński A., Kanonicy regularni od pokuty na ziemiach polskich, Kraków 2003.

Chomentowska E., Schematyzmy zakonów męskich z ziem dawnej Rzeczpospolitej z lat 1718-1918. Studium źródłoznawcze, Lublin 2016.

Gołuszka M., Jaśnieoświeconego księcia biskupa krakowskiego Andrzeja Stanisława Zatuskiego drukarnia w Krakowie 1749-1758, w: Drukarze dawnej Polski od XV do XVII wieku, t. 1, Małopolska, cz. 2, Wiek XVII-XVIII, vol. 2, L-Ż i drukarnie żydowskie, red. J. Pirożyński, Kraków 2000, s. 262-268.

Grzeszczuk M., Grebel Ignacy, w: Drukarze dawnej Polski od XV do XVII wieku, t. 1, Małopolska, cz. 2, Wiek XVII-XVIII, vol. 1, A-K, red. J. Pirożyński, Kraków 2000, s. 224-235.

Grzeszczuk M., Matyaszkiewicz Jakub, w: Drukarze dawnej Polski od XV do XVII wieku, t. 1, Małopolska, cz. 2, Wiek XVII-XVIII, vol. 2, L-Ż i drukarnie żydowskie, red. J. Pirożyński, Kraków 2000, s. 426-434.

Grzeszczuk M., Stachowicz Stanisław, w: Drukarze dawnej Polski od XV do XVII wieku, t. 1, Małopolska, cz. 2, Wiek XVII-XVIII, vol. 2, L-Ż i drukarnie żydowskie, red. J. Pirożyński, Kraków 2000, s. 594-599. 
Jaglarz M., w: Drukarze dawnej Polski od XV do XVII wieku, t. 1, Małopolska, cz. 2, Wiek XVII-XVIII, vol. 2, L-Ż i drukarnie żydowskie, red. J. Pirożyński, Kraków 2000, s. 561-562.

Kalendarz, w: Encyklopedia wiedzy o książe, red. A. Birkenmajer i J. Trzynadlowski, Wrocław-Warszawa-Kraków 1971, kol. 1087-1092;

Kicińska-Fujawa A., Akademii Krakowskiej Drukarnie, w: Drukarze dawnej Polski od XV do XVII wieku, t. 1, Małopolska, cz. 2, Wiek XVII-XVIII, vol. 1, A-K, red. J. Pirożyński, Kraków 2000, s. 39-69.

Konarska-Zimnicka S., Konferencja naukowa , Rubrycele i schematyzmy Kościoła w Polsce, Kielce 23-25 maja 2014, „Archiwa Biblioteki i Muzea Kościelne”, 102 (2014), s. 438-446.

Konieczny A., Rubrycela, w: Encyklopedia katolicka, t. 17, red. E. Giglewicz, Lublin 2012, kol. 513-514.

Korotajowa K., Cezary, w: Drukarze dawnej Polski od XV do XVII wieku, t. 1, Małopolska, cz. 2, Wiek XVII-XVIII, vol. 1, A-K, red. J. Pirożyński, Kraków 2000, s. 78-82.

Kumor B. S., Dzieje diecezji krakowskiej do roku 1795, t. 2, Kraków 1999.

Kumor B, Granice (archi)diecezji krakowskiej (1000-1939), „Prawo Kanoniczne. Kwartalnik prawno-historyczny", 6 (1963), nr 1-4, s. 535-556.

Kwaśniewski A., Rubrycele i elenchusy diecezji krakowskiej z lat 1801-1848, „Świętokrzyskie Studia Archiwalno-Historyczne", 3 (2014), s. 205-245.

Librowski S., Katalog rubrycel i schematy zmów diecezji i zakonów historycznej Polski znajdujacych się w Księgozbiorze Podręcznym Archiwum Diecezjalnego we Włocławku. Cześć 1: Rubrycele i schematyzmy diecezjalne. Zeszyt 1: Diecezja augustowska - archidiecezja krakowska, 23 (1971) s. 213-310.

Librowski S., Katalog rubrycel i schematy zmów diecezji i zakonów historycznej Polski znajdujacych się w księgozbiorze podręcznym Archiwum Diecezjalnego we Włocławku. Część 1: Rubrycele i schematyzmy diecezjalne. Zeszyt 2: Diecezja lubelska-diecezja płocka, 24 (1972) s. 5-94.

Librowski S., Katalog rubrycel i schematyzmów diecezji i zakonów historycznej Polski znajdujacych się w ksieggozbiorze podręcznym Archiwum Diecezjalnego we Włocławku. Część 1: Rubrycele i schematyzmy diecezjalne. Zeszyt 3: Diecezja podlaska-diecezja warmińska, 25 (1972) s. 39-113.

Librowski S., Katalog rubrycel i schematyzmów diecezji i zakonów historycznej Polski znajdujacych się w księgozbiorze podręcznym Archiwum Diecezjalnego we Włocławku. Część 1: Rubrycele i schematyzmy diecezjalne. Zeszyt 4: Archidiecezja warszawska-diecezja żmudzka, 26 (1973) s. 89-197.

Librowski S., Katalog rubrycel i schematyzmów diecezji i zakonów historycznej Polski, znajdujacych się w księgozbiorze podręcznym Archiwum Diecezjalnego we Włocławku. Część 2: Rubrycele i schematyzmy zakonne, 27 (1973) s. 57-130.

Majkowska R., Archiwum kościoła św. Marka w Krakowie, „Nasza Przeszłość”, 71 (1989) s. $137-145$.

Murawiec W., Wyczawski H., Banaczkowski Szymon, w: Słownik polskich teologów katolickich, red. H. Wyczawski, t. 1, Warszawa 1981, s. 95-96

Müller W., Szczygielski W., Młodziejowski (Młodziejewski) Andrzej Mikołaj, w: Polski Sownik Biograficzny, t. 21, red. E. Rostworowski, Wrocław 1976, s. 428-432.

Nowak A., Słownik biograficzny kapłanów diecezji tarnowskiej 1786-1985, t. 2-3, Tarnów 2000-2004.

Pękalski P., O początku, rozkrzewieniu i upadku Zakonu XX. Kanoników Stróżów św. Grobu Jerozolimskiego, Kraków 1867.

Pidłypczak-Majerowicz M., Badania proweniencyjne w bibliotekach kościelnych, „Fides. Biuletyn Bibliotek Kościelnych”, 2014 nr 1 (38) s. 3-14. 
Rouez S., Les cérémonies en l'honneur de la béatification et de la canonisation de Jeanne de Chantal. Entre dévotion privée des visitandines et dévotion publique, „Revue Mabillon", 13: 2002, t. 74, s. 265-302.

Szady B., Kościół i społeczeństwo Małopolski w II połowie XVIII w. Materiały źródłowe, t. 1, Ludność i organizacja diecezji krakowskiej, Lublin 2010.

SzczepaniakJ. Duchowieństwo diecezji krakowskiej: studium prozopograficzne, Kraków 2010 .

Szymański J., Kapituła kolegiacka w Wojniczu 1465-1786, Lublin 1962.

X. M. S. [M. Stefanowski], Rubrycela, w: Podręczna encyklopedya kościelna, red. S. Gall, J. Gautier, R. Jałbrzykowski i.in., t. 23-24, Warszawa-Lublin-Łódź 1914, s. 853.

X. S. Ch. [S. Chodyński], Dyrektorium, directorium, w: Encyklopedja Kościelna podtug teologicznej encyklopedji Wetzera $i$ Weltego z licznemi jej dopetnieniami, wyd. Nowodworski, t. 4, Warszawa 1874, s. 416-420.

\title{
LITURGICAL CALENDARS OF THE DIOCESE OF KRAKÓW FROM 1735-1811, KEPT IN THE REFERENCE LIBRARY OF THE ARCHIVES OF THE METROPOLITAN CURIA IN KRAKÓW
}

\begin{abstract}
The reference library of the Archives of the Metropolitan Curia in Kraków has the largest known collection of liturgical calendars printed for the needs of the clergy of the Diocese of Kraków. The collection has been almost complete since the mid-18th century.

According to the modified classification adopted by Rev. Stanislaw Librowski, Kraków's liturgical calendars can be divided into four types, closely related to the phases of their development. The first type includes liturgical calendars issued without any additions (16th century to 1750), the second type includes calendars with a list of deceased clergymen (from 1751) and a catalogue of prelates and cathedral canons (from 1753). The third type of liturgical calendars includes printed materials connected with the full catalogue of parishes and clergy (from 1811 onwards), and the fourth type includes independent prints which contain a separate liturgical calendar and the diocesan schemes, appeared as late as 1871 .

Until the end of the 18th century, the cathedral chapters were usually responsible for issuing the liturgical calendars. One of cathedral canons or vicars, whose name was usually given on the title page, developed the text on behalf of an ordinary bishop or vicar capitular. The chapter was responsible for printing and distributing the calendar. In Kraków, the calendar was edited by successive deputy deans of Wawel Cathedral, who at the same time were canons of St George's Collegiate Church at Wawel.

Preserved copies of the calendars include the signatures of their owners, which allow us to learn the history of the collection. Many of the preserved copies of the calendars also contain remarks made by the owners. These refer to spiritual and economic issues, providing information on important matters for the clergy.

Keywords: liturgical calendars; diocese of Kraków; schemes (catalogues) of the clergy; vicars of Wawel Cathedral; Collegiate Church of St George at Wawel; printing houses in Kraków (18th century).
\end{abstract}

